\title{
International Business and Institutional Development in Central and Eastern Europe
}

\author{
MODESTAS GELBUDA \\ CIBER Vilnius \\ Lithuania
}

\author{
KLAUS E. MEYER \\ School of Management \\ University of Bath \\ Bath BA2 7AY \\ United Kingdom \\ Email: km.cees@cbs.dk \\ http://www.klausmeyer.co.uk \\ ANDREW DELIOS \\ NUS Business School \\ National University of Singapore \\ 1 Business Link \\ Singapore, 117582 \\ Republic of Singapore \\ Tel: 65-6516-3094 \\ Fax: 65-6779-5059 \\ Email: andrew@nus.edu.sg
}

Forthcoming in: Journal of International Management

This version: 22 May 2007

This file has been obtained from www.klausmeyer.co.uk 


\title{
International Business and Institutional Development in Central and Eastern Europe
}

\begin{abstract}
.
Since the early 1990s, Central and Eastern Europe has attracted international business research into the interaction between radical societal change and business development in these emerging market economies. This research has effectively utilized institutional theories, and thus revealed limitations of similar applications in other contexts, while setting the stage for more refined argumentations, especially with respect to rapidly changing contexts. This introductory paper outlines both economic and the sociological perspectives on the influence of institutions on business, and thus sets the stage for this Special Issue. On this basis, we introduce the five papers in this special issue, and outline an agenda for future research.
\end{abstract}

Acknowledgements: We are grateful for financial support received from CIBER Vilnius, and the National University of Singapore (NUS Academic Research Grant R-313-000095-112). We thank the core organizers of the Third International Conference on International Business in Transition Economies: CIBER Vilnius, The Stockholm School of Economics in Riga, and IBE Research Group at Aalborg University. We also want to extend our deep appreciation to the reviewers who generously devoted their time and expertise to the reviews for this Special Issue (Appendix 1). 


\section{Introduction}

Since the opening of the Central and Eastern European (CEE) economies to international business (IB) in the early 1990s, the region has not only attracted increasing amounts of foreign direct investment (FDI) and international trade; it has also attracted a commensurate amount of academic research. The initial work on CEE countries focused on understanding the peculiarities of the transition economy context (Meyer, 2001b), or testing the validity of mainstream theories in a new, emerging context. As time progressed, scholars have altered their research strategies to focus on adapting existing theories that the unique context and phenomena, or to develop new theories to explain IB activities in the transition context. This literature has found that an institutional perspective has been a useful framework from which to base our growing understanding of the relevant IB issues in these transition economies (Wright, Filatotchev, Hoskisson and Peng, 2005). More importantly, CEE research has started to contribute back to the mainstream literature in management and international business (Meyer and Peng, 2005).

Along with this growing contribution to the core of management and IB research has come an increased density of research on IB in CEE economies, conducted by scholars not resident in the region, and also by scholars resident in the region. Indeed, researchers with a CEE heritage increasingly participate in international scholarly discourses, thus bringing a strong, visceral understanding of context, to merge with research methods championed in European and North American institutions. This merger of context knowledge and methods is similar to what has been occurring in management and IB research in Asia (White, 2002). Also, similar to research conducted in the transition economies of Asia in the early 2000s, research on transition economies in the 
CEE increasingly employ institutional perspectives. This emphasis is reflected in this Special Issue, where institutions and IB have emerged as a dominant theme.

In some ways, the focus on institutions is not surprising. The economy wide institutional changes in CEE countries created challenges for business on multiple levels (World Bank, 1996; Meyer, 2001b; Peng, 2001; Svejnar 2002). In the late 1980s, the then socialist economies had established a rigid set of formal institutions organized around a nation-wide central plan. In parallel, informal institutions, such as blat networks, allowed individuals and firms to operate, often against the spirit of the socialist agenda, if not in an outright illegal fashion.

At the outset of transition, the existing formal institutions in most CEE countries collapsed. After this collapse, new formal institutions began to emerge, but only gradually. In the interim, in some periods organizations faced a regulatory vacuum with incomplete legal frameworks and ambiguous social norms. At other times, firms and entrepreneurs faced fragmented, overlapping and contradictory legislation, and informal norms persisting from the socialist past and evolving only slowly. The norms of business continued to be closely aligned with socialism, more so than with a competitive market economy. These norms existed even as formal institutions transited towards those characterizing a market-based economy. Moreover, cognitive barriers inhibited managers' understanding of how best to operate under the conditions of a volatile market economy (Meyer and Gelbuda, 2006).

As transition progressed, new formal institutions have been created and legitimized through legal reforms, often inspired by examples in Western Europe and North America. This emergence of new formal institutions has been comparatively fast; 
yet substantial barriers continue to inhibit business transactions in a market economy. These barriers emerged from the inertia that characterizes informal institutions based in the norms and cognition of individuals. Changing informal institutions is a much more complex, time-consuming and less well understood process than changing formal institutions (North, 1990). Thus, the conduct of business operations in transition economies has faced a prolonged period of inconsistent institutions and the consequent high uncertainty on how best to operate during this time of institutional change.

This context of transition and the variable paces of change in formal and informal institutions has provided scholars with a unique opportunity to study the interaction between firms and their environment, and thus to advance our understanding of institutional influences on management and international business. The papers in this Special Issue address such issues, which we also reinforce in this introductory paper. We review the contribution of two interrelated lines of theorizing on institutions, namely institutional economics (North, 1990) and the sociology-grounded institutional theory (Scott, 1995), to explaining business in CEE, and our understanding of business in general. From this base, we then introduce the five papers in this Special Issue on International Business and Institutional Development in Central and Eastern Europe, where we also identify the process and the key individuals involved in the development of this Special Issue.

\section{An Economics Perspective on Institutions}

Scholars investigating institutions and business in transition economies typically develop their arguments in the tradition of institutional economics (North, 1990) rather than the 
form of institutional theory that characterizes research in organizational behaviour, organization theory and sociology (Meyer and Rowan 1977; DiMaggio and Powell, 1983; Scott, 1995). Accordingly, scholars looking at transition issues typically focus on the specific incentives generated by the institutions in the environment of the organization or the individual decision maker. In this line of theorizing, decision makers are maximizing their utility consistent with standard assumptions in economics.

This institutional economics approach is rooted in the idea that the institutional environment is critical to shaping economic activity and firm behavior. North (1990) conceptualizes a nation's institutions as the rules of the game that comprise informal constraints (sanctions, taboos, customs, traditions, and codes of conduct) as well as formal rules (constitutions, laws, property rights). This includes for instance laws and regulations for purchasing property, licensing of new businesses, hiring workers, importing and exporting regulations, rules on capital repatriation, standards for contracting with suppliers and buyers, process for obtaining licenses and the way to pay taxes. In a branch of this research, a "formal rules" perspective of a nation's institutions specifically emphasizes the political (Henisz, 2000) and legal (Greif, 1993; La Porta et al., 1998; Levine \& Zervos, 1998) aspects of institutions.

These rules and regulations influence the efficiency of markets and thus the transaction costs that firms and individuals would face when doing business in these markets. For instance, transparency affects the costs of identifying and evaluating potential business partners, and the protection of property rights affects the costs of writing and enforcing business contracts. Businesses adapt to these environmental influences on their transactions when deciding where and how to do business. Hence they 
would stay out of markets that are particularly inefficient, or they may adapt suitable organizational forms to manage these costs - for instance internalization within a firm, or use of business networks.

Similarly, institutional arrangements affect the efficiency of agency relationships and systems of corporate governance in particular. Researchers have used agency theory complemented with institutional considerations as primary reference points to analyze the privatizations in CEE in the 1990s and the subsequent new ownership arrangements. This work has thus pointed to adverse incentives, to help explain why, despite a widespread change of ownership, many former state enterprise were slow to improve their economic performance (Megginson and Netter, 2001; Estrin, 2002; Filatotchev et al., 2003).

Research on IB issues in the transition economies of Asia and the CEE has focused on the challenges facing MNEs when operating in its varied host country markets, in particular how to adapt their systems, structures and strategies in nations that provide a less sophisticated legal framework than, say, Western Europe and North America. One line of research investigates the effects of "weak" institutional frameworks on MNEs' propensity to do business in that location. For instance, Bevan et al. (2004) find some aspects of institutional development facilitate FDI inflows, while other aspects do not. Javorcik (2004) finds that weak intellectual property rights inhibit FDI in high technology sectors.

Another line of research has explored how firms adapt their organizational forms to high costs of doing business in certain markets. This work has shown that, in transition contexts, domestic firms are more likely to rely to a larger extend on network based strategies (Peng and Heath, 1996), while foreign investors make more use of joint 
ventures (Meyer, 2001; Meyer and Nguyen, 2005) and customize forms of FDI to overcome inefficient markets. For instance, where market access to local resources is costly, firm may acquire a local firm that controls specific assets, and then soon replace most of the firm's other assets, in a form of brownfield acquisition (Meyer and Estrin, 2001). On the other hand, where inefficient markets for corporate equity inhibit full acquisitions, MNEs use staged acquisitions or they incorporate parts of an existing local firm into a JV (Meyer and Tran, 2006).

A related line of work has focused on institutional distance and thus the adaptation that MNEs face when investing in a context with different institutions. Larger institutional distance between a firm's host and host countries tends to increase the challenges to doing business in the host country (Xu and Shenkar, 2002). As differences grow larger, the costs and risks of doing business increase concomitantly, or perhaps even geometrically. Accordingly, as a first and important step to effectively deploying its resources in a host country, a firm's managers need to not only identify the points of difference in institutional environments between the host country and the other country markets in which it has previously operated, but the managers must also develop a strategy to contend with these differences (Martin, Swaminathan and Mitchell, 1998; Zaheer, 1995). The strategic elements that tend to be deployed to manage institutional differences include the timing and mode of entry, the types of business activities conducted in a country, the products that are introduced, HRM strategies and various forms of alliances.

Similarly, differences in informal institutions can influence the costs of doing business. For example, research on the cultural dimension of national institutional 
environments points out how cross-national differences in culturally-rooted business practices can create difficulties in transferring one model of management from one country to another (Guillén, 2000). Although firms can formulate strategies to contend with institutional differences, one consequence of institutional distance is that as it increases, a firm becomes less likely to enter a particular country. Meanwhile if an investment does occur, the investor becomes more likely to enter by a joint venture.

IB scholars studying institutions on the basis of economics inspired theorizing thus focus on external constraints and the costs of doing business, especially transaction and agency costs, as well as the adaptation costs related to operating in a different institutional environment. Businesses react to these constraints and costs either by staying out of the country, or by adapting their organizational forms. A shared assumption in this work is the 'rational economic actor' maximizing its utility, an assumption that is not necessarily shared by work in sociology inspired research.

\section{A Sociological Perspective to Institutional Theory}

Sociological perspectives to institutional theory have been applied to numerous strategic issues in a firm. These applications have been made with the goal, implicit or explicit, of overcoming limitations inherent to the rational choice models that dominate economic perspectives on decision-making in organizations (Fligstein \& Dauber, 1989).

Unlike the institutional economics perspective, sociology-based institutional theory conceptualizes institutions as the rules and norms that define legitimate behavior (DiMaggio \& Powell, 1983; Zucker, 1987). In a sociology-based institutional theory perspective, organizations conform to the prevailing belief systems of the society to 
obtain legitimacy (Deephouse, 1996; Suchman, 1995). With gains in legitimacy comes enhanced access to resources (D’Aunno et al., 1991) and stronger social-psychological support from the external environment. Notably, this legitimacy and support can emerge even if the actions and decisions that foster legitimacy are at odds with efficiency requirements of the firm (DiMaggio \& Powell, 1983; Meyer \& Rowan, 1977). That said, organizational survival and effectiveness, however, cannot last long without attention to technical considerations, meaning that such considerations cannot be obviated or subverted to legitimacy considerations for a prolonged period of time (Meyer \& Scott, 1983). Accordingly, a sociology-based institutional theory perspective has often been combined with efficiency-based theories to explain firm behavior and strategy (Eisenhardt, 1988; Oliver, 1997).

Interestingly, even given their different disciplinary heritages, both economics and sociological institutional theory perspectives emphasize the importance of the "formal rules" of a nation in regulating or influencing organizational behavior in the context of international business decisions. Institutional theorists embrace the point that coercive isomorphism (DiMaggio \& Powell, 1983), or the rules developed and supported by law and the government (Scott, 1987; Starbuck, 1976), are important to defining costefficient and legitimate behavior for a firm, and thereby serve as an isomorphic force.

In fact, the isomorphic forces that underlie institutional theory emerge from the "three pillars" of institutions - regulatory, normative, and cognitive - found in Scott's (1995) conceptualization. The regulatory pillar corresponds to the "formal rules" definition of institutions in institutional economics, hence creating the alignment between the two perspectives, at least at some level. Importantly, as well, the institutional 
environment of an MNE consists not only of the formal realm, but it comprises these multiple, but separate and distinctive, domains (Kostova \& Zaheer, 1999).

For example, subsidiaries of MNEs may gain external legitimacy by conforming to the regulatory rules of the political-legal institutions in its host country. Even if legitimacy can be obtained, one must also recognize that across nations institutions differ in the level of support they provide to business organizations, with this difference varying not only across CEE countries, but also within CEE countries over time. This crossnational and temporal variance in the strength of institutions is one of the more fortuitous aspects of these environments for researchers in IB.

The difference in the strength in institutions is important for a number of reasons. Strong institutions provide legitimacy and social-psychological support, as well as material benefits, such as reductions in transaction and production costs, that are conducive to the efficient operations of a firm. Even if weak institutions do not provide such explicit support for business transactions, weak institutions still can provide legitimacy and social-psychological support, provided that firms conform to local rules and norms (King \& Levine, 1993; Levine \& Zervos, 1998). The risk in such conformance in a weak institutional environment is that the laws and rules in institutionally weak countries can be incompatible with the efficiency requirements of a firm, such as the protection of property rights (La Porta et al., 1998) and freedom from government corruption (Henisz, 2000).

Another important development in institutional theory pertinent to the CEE context is the idea that organizations can be situated in multiple institutional fields 
(Hoffman, 1999). Such firms encounter multiple institutional pressures (D’Aunno, et al, 1991; Singh et al., 1986), to which they must respond strategically (Oliver, 1988; 1991).

This multiple institutional field perspective has been exploited by researchers in IB who have taken this institutional theory perspective to view subsidiaries as being subject to at least two groups of institutional forces: those that emanate from local firms and organizations in the host country, and those that come from the parent firm and other units in a multinational firm (Westney, 1993; Rosenzweig \& Singh, 1991). As CEE scholars grapple with this multiple institutional field perspective, which might also be present in a CEE country on a temporal basis as it transitions from a centrally-planned to a market-based economy (Karhunen, 2007), it becomes important to consider the basic but essential point that conforming to local rules and norms provides external legitimacy for a subsidiary (Kostova \& Zaheer, 1999; Rosenzweig \& Nohria, 1994). Yet such legitimacy related gains need to be balanced against the need for internal coordination and efficiency within an MNE’s system (Ghoshal \& Bartlett, 1990; Westney, 1993).

The recognition of multiple institutional perspectives raises an important research question. Specifically, how can core organizational actors standing at the cross-roads of institutions, absorb and handle multiple and contradictory demands coming from different institutional fields? Fligstein (1999) proposes the concept of social skill to explain how skilled actors induce cooperation from others and achieve desired outcomes in multi-organizational fields. However, little empirical research has been carried out by IB scholars studying firm’s operations in multiple institutional fields.

Similar to economics based work on institutions, empirical research motivated by this line of theory focuses on two key decisions in IB. This first concerns the decision 
about which market to enter (Mayer and Mucchielli, 1998; Ford and Strange, 1999; Guillén 2002; Henisz and Delios, 2001), and the second concerns the choice of entry mode (Davis, Desai, and Francis, 2000; Lu, 2002; Yiu and Makino, 2002).

Within both lines of work, but most pronounced in the entry mode research, a major theme is the role of uncertainty. Uncertainty tends to be tied to the prevalence of imitation. Imitation in organizational structures and strategies emerges as a consequence of isomorphic pressures that lead to conformity in the expectations of key actors, or to conformity in the actions of peers in a market. Such pressures for conformity naturally lead to imitation in the decisions and actions of follower firms with leader forms and a consequent similarity in organizational structures and strategies (Kostova, 1999; Kostova and Zaheer, 1999; Guillén, 2000).

In terms of arguments specific to institutional theory, the pressure for conformity in the entry mode choice can come from the regulatory environment (Yiu and Makino, 2002). Research on organizations has also shown that uncertainty about the three pillars of the institutional environment can increase the importance of social considerations relative to technical considerations (Festinger, 1954; DiMaggio \& Powell, 1983; Haunschild and Miner, 1997). When a decision is marked by uncertainty, social considerations become more important, leading to the point that a prominent influence on a decision is the set of actors in a firm's immediate inter-organizational environment (Hannan and Carroll, 1992). Given uncertainty, an organization looks to the decisions of other organizations to provide a guide (Tolbert and Zucker, 1983), with the result being that as a large number of organizations engage in a decision, it becomes common knowledge, or a rule of thumb, to implement the same decision (March, 1991). In the IB 
setting, there is good evidence to support this line or reasoning, as, for example, researchers have found that a firm's propensity to utilize joint ventures is jointly dependent on the frequency of use of joint ventures by peer firms as well as the level of uncertainty in an environment ( $\mathrm{Lu}, 2002)$. If uncertainty is less, or the density of prior entries by joint ventures is lower, then the prevalence of joint venture entry by new entrants also declines.

\section{The Two Institutional Perspectives and Research in CEE Countries}

Both the institutional economics perspective and the sociology-based institutional theory perspective have their own respective merits for explaining and understanding phenomenological issues indigenous to firms operating in international business in CEE countries. Even with the merits of both approaches, scholars on transitional economies have had the aforementioned emphasis in their work based in the institutional economics perspective. This emphasis has emerged presumably because the incentives and the relative costs of alternative organizational forms are quite different in transition economies than they are in the Anglo-American societies typically commonly used as benchmarks in management research. Thus, an institutional economics perspective has helped us to explain the unique features of formal and informal institutions in transition economies. These perspectives have also helped to understand the often unstated limitations of work conducted in other contexts; such as the taken-for-granted efficiency of many markets in western Europe and North American economies, which is in fact a consequence of the institutions in these economies. 
Even with the comparative underutilization of a sociological perspective on institutions, we do believe that such a perspective holds substantial perspective to inform management and IB issues in CEE countries. Recent work in the IB area that has applied such an institutional theory perspective to analyze business strategies in China (Yiu and Makino, 2002; Lu and Xu, 2006) has yielded such insights, and we believe that our knowledge of theoretical and empirical issues could similarly be expanded through the application of this perspective to IB issues in CEE. Future research can explore comparative questions, such as whether the differences in the transition contexts between the CEE and China, for instance, yields substantially different influences or consequences of institutional pressures. In China, a stable political system created the need to attain legitimacy with established institutions and individuals in positions of influence. In CEE countries in the early 1990s, the existing structures disintegrated to the extent that firms that may have tried a somewhat different strategy in which legitimacy was achieved by alignment with the new economic system and a high distance from the old institutions.

Work set in an institutional vein in CEE can continue to expand on the importance between institutional change and organizational change. This work can build from the observation that it is at points of inflection of institutional evolution in an economy that frictions between a firm's strategies and their degree of institutional alignment become most pronounced. This interaction between institutional change and organizational change is particularly well-suited to examination in a CEE context because of the continued temporal dynamics of these processes, and the opportunities for comparative cross-national research in the CEE, where many nations have undergone different forms of transition (Meyer and Peng, 2005; Meyer and Gelbuda, 2006). 
Some management scholars synthesize, or selectively combine, the two strands of closely related theoretical work (Peng, 2003; Peng et al., 2005). This approach however disguises the subtle differences between the economics and sociology inspired work. To deepen the theoretical grounding of future research, we feel it is helpful to be clear about the arguments and the underlying assumptions of each body of research on institutions. We hope that such an approach will stimulate more rigorous theoretical reasoning about the relationships between institutions and business strategies.

\section{Papers in the Special Issue}

We are pleased that two of the five studies in this Special Issue have implemented a longitudinal design to examine issues of transition. This type of research design allows a researcher to compare businesses at different points in time, and thus in different contexts, which permits a deeper understanding of the processes and direction of adjustment during this time of institutional change and organizational change.

Interestingly, we have found that the papers in this Special Issue, and the submissions themselves, had a high incidence of origin from researchers based in Nordic countries. Our final set of accepted papers includes two papers each from Sweden and Finland, and one from a scholar based in the US. This high profile of Nordic countries in CEE research may be due to the continued interest in business with CEE due to the geographic proximity to the Nordic countries, and the importance of the development of CEE countries to the economic prospects of firms in Nordic countries. In this sense, this Special Issue provides us with an opportunity to showcase Nordic research, which has 
played an important role in International Business and International Management research for decades.

The papers in this special issue draw on the inductive and qualitative dimensions that are an important component of the Nordic research tradition. Scholars in this tradition engage in field work with relevant business communities, and their contribution is often in form of a theoretically grounded interpretation of the observed data, rather than testing theory with archival data the method that characterizes research situated firmly in the deductive realm. Although the research methods and traditions of the Nordic community of IB researchers may have its inherent weaknesses, such as with respect to the generalizability of the results, we share the view of March (2005) that continuing dialogue and thus a loose coupling of research agendas of different scholarly communities can potentially best enhance global management knowledge.

\section{*** insert Table 1 approximately here ***}

This special issue has five papers (Table 1). They share a number of common traits while demonstrating the variety of theories and methods used in contemporary research on CEE. Four papers explicitly focus on the institutional context as the main variable under investigation, while Jansson and Sandberg (2007) investigate internationalization processes in a specific context, thus controlling for contextual variation. Four papers employ an inductive method of analysis, aiming to build theories from mainly qualitative data. However, Cuervo-Cazurra (2007) employs a deductive approach in testing theoretically-grounded hypotheses.

The first paper by Alvaro Cuervo-Cazurra (2007) investigates the impact of corruption on a country's attractiveness as a host country for foreign direct investment. 
Conventional wisdom suggests that high levels of corruption would negatively affect the general business climate, raising the costs of doing business and thus deterring foreign investors. However, Cuervo-Cazurra finds evidence that this conventional wisdom may not suffice to explain patterns of foreign direct investment. In particular, a more nuanced understanding of corruption is required to understand its influence on FDI. The type of corruption in terms of its pervasiveness and arbitrariness may be crucial to understand when and why corruption deters FDI. Further, these effects may be different in transition economies compared to developing or developed economies. Pervasive corruption adds to the costs of doing business, while arbitrary corruption adds to the uncertainty affecting business. Cuervo-Cazurra finds empirical support for his proposition that in transition economies arbitrary corruption may be perceived as part of an institutional environment that has an already high level of uncertainty, and, as such, it would thus not have an additional negative effect on the attractiveness of this country to foreign investors.

Päivi Karhunen (2007) investigates the interactions of different types of firms in a very specific organizational field within an institutional environment, tracing the changing pattern of such interactions over time. She conducted an in-depth longitudinal study with rich evidence derived from interviews in the St. Petersburg hotel industry. On this basis, she argues that organizations respond strategically to institutional forces, pointing out that some organizations follow institutions while others flaunt them. Moreover, the 'institutional strategies' of different St. Petersburg hotels depend on the type of firm (foreign or domestic) and the era in which they were founded (pre- or post reform). This suggestion to link institutional response more precisely to status under institutions or to organizational resources provides a promising avenue for future research. 
Martin Johanson (2007) also conducts a longitudinal study focusing on a single industry over a long time period covering both pre-transition and early transition conditions. He investigates the role of trust in intra- and inter-firm relationships, focusing on the role of institutions in shaping the characteristics of exchange relations, and thus indirectly in the role of trust in facilitating business. In particular, the changes in the institutional setting at the onset of transition increase the need for knowledge exchanges and the intensity of interactions, while reducing the stability of relationships. In the absence of a strong legal framework, this increases the requirements for inter-personal trust for business transitions during early stages of an economy's transition. This work raises the challenging question of whether a stable market economy with strong legal enforcement mechanisms would require less inter-personal trust than an economy requires during a volatile transition period.

Jansson and Sandberg (2007) undertake an interesting extension of the internationalization process model in their examination of the international activities of 116 SMEs from southern Sweden in the Baltic States, Poland and Russia. This extension comes from their bridging of ideas from industrial network analysis with the internationalization process model how these SMEs have entered these transition economies. Jansson and Sandberg make an interesting differentiation between entry nodes (the relationship points that are developed in the foreign entry process) and entry modes (licensing, exporting, joint venture entry, wholly-owned entry) in their development of the Five/Five Stages model, as they call it. In the development of this model, they discuss the importance of dyadic relationships, which exist between the focal firm and its customers, and triadic relationships, or those relationships between a focal 
firm and its customers that are mediated by distributors or agents. The variance in use of dyadic and triadic forms of entry have important trade-offs between the facilitation and reduction of risk in international entry, and the potential for gains or losses in opportunities to learn about foreign markets. This trade-off represents an important extension to the internationalization process model in the sense that it helps to identify situations in which learning about foreign markets may or may not accompany entry into a foreign market.

Päivi Karhunen, Joan Löfgren and Riitta Kosonen (2007) investigate relationships between ownership and control in a foreign entrant's operations under the specific institutional context of Russia during its transition period. Although degrees of control and ownership are often positively correlated, this paper outlines conditions under which foreign investors may choose to be a 'hands-on'contractor' with high degrees of control but little equity investment, or a 'market share maximizer' with investment in equity but limited control. These forms of business are not unheard of in other business contexts (Yan and Gray 2001), yet this paper outlines why firms may find such arrangements to be particularly suitable to deal with the institutional peculiarities of the transition context. ${ }^{1}$

\section{Special Issue Selection Process and Acknowledgements}

These five papers emerged from our process for identifying, receiving and reviewing papers for the Special Issue. After generously receiving support for the Special Issue from the Journal of International Management, we issued the call for papers in 2004 with

\footnotetext{
${ }^{1}$ It may be unusual to have two papers by the same author in a special issue. These papers were submitted and reviewed independently by different reviewers. None of the authors has been related to any of the editors. Subsequent to completing the paper review process, one of the editors was invited to serve as opponent for the PhD defense of Paivi Karhunen at Helsinki School of Economics.
} 
the first deadline for submissions being May 2005. After receipt of our first tranche of submissions, we issued a second call for papers with the final deadline for submissions being September 2005.

These calls for paper built on a conference on "International Entrepreneurship, Management and Competitiveness in Transforming and Emerging European Economies” held in Vilnius, Lithuania in 2004. Reflecting the orientation of this conference, the first and second call for papers were made under a fairly broad topical area. Once we received the papers, and completed our review process, we found that the accepted papers had a much tighter topical focus than the original call for papers for this Special Issue. Accordingly, we decided to publish this special issue under a more focused title that reflects the conceptual orientation of the researchers investigating business issues in transition economies.

Notably, our two calls for papers resulted in a total of 41 submissions being received. Twenty-three submissions were sent for review, with the others being deskrejected in a consultative process across the three editors for the Special Issue. Each of the papers that went out for review was reviewed by two or three anonymous reviewers. We took special care to utilize reviewers with different perspectives, such that papers typically had reviewers that were either part of the Anglo-American research tradition, or were from a European research tradition with good knowledge of the issues pertinent to firms competing in the CEE.

Overall, we were very pleased to have support from these two research communities, and we greatly appreciate the timely and insightful comments that our reviewing team provided to the authors in their reviews. We wish to thank the reviewers 
for their support in preparing this special issue, they are listed in Appendix 1. Moreover, we also want to thank the CIBER in Vilnius, Lithuania for the administrative support provided for this Special Issue. Finally, we would like to extend our gratitude to the authors that contributed their research to the Special Issue. It was a delight to read the contributions, whether published herein or not, and we feel much better informed about issues in the CEE and in IB as a consequence. We sincerely hope and believe that this Special Issue holds similar value to our research and practice community. 


\section{References}

Bevan. A., Estrin. S., Meyer. K.E. 2004. Foreign investment location and institutional development in transition economies, International Business Review 13: 43-64.

Cuervo-Cazurra, A. 2007. Better the devil you don't know: Type of corruption and FDI in transition economies. Journal of International Management, this issue.

D’Aunno, T., Sutton, R. I., Price, R. H. 1991. Isomorphism and external support in conflicting institutional environments: A study of drug abuse treatment units. Academy of Management Journal, 34, 636-661.

Davis, P., Desai, A., Francis, J. 2000. Mode of international entry: an isomorphism perspective. Journal of International Business Studies, 31, 239-258.

Deephouse, D. L., 1996. Does isomorphism legitimate?. Academy of Management Journal, 39, 1024-1039.

DiMaggio, P. J., Powell, W.W. 1983. The Iron Cage Revisited: Institutional Isomorphism and Collective Rationality in Organizational Fields. American Sociological Review, 48, 147-160

Eisenhardt, K. M., 1988. Agency- and institutional-theory explanations: The case of retail sales compensation. Academy of Management Journal, 31, 488-511.

Estrin, S., 2002. Competition and corporate governance in transition. Journal of Economic Perspectives, 16: 101-124. 
Festinger, L., 1954. A Theory of Social Comparison Processes. Human Relations, 7:117140.

Filatotchev, I., Wright, M., Uhlenbruck, K., Tihanyi, L., Hoskisson, R.E. 2003 Governance, organizational capabilities, and restructuring in transition economies, Journal of World Business 38 , 331-347.

Fligstein, N., Dauber, K. 1989. Structural Change in Corporate Organization, Annual Review of Sociology, 15: 73-96.

Fligstein, N. F., 1999. Power, and social skill: A critical analysis of the new institutionalism. Berkeley: University of California.

Ford, S., Strange, R., 1999. Where do Japanese manufacturing firms invest within Europe and why? Transnational Corporations, 8:117-142.

Ghoshal, S., Bartlett, C. A., 1990. The multinational corporations as an interorganizational network. Academy of Management Review, 15, 603-625.

Greif, A., 1993. Contract enforceability and economic institutions in early trade: The Maghribi traders' coalition. The American Economic Review, 83, 525-548.

Guillén, M. F., 2000. Business groups in emerging economies: A resource-based view. Academy of Management Journal, 43, 362-380.

Hannan, M. T., Carroll, G. R., 1992. The Dynamics of Organizational Populations. New York. Oxford University Press. 
Haunschild, P., Miner, A., 1997. Modes of interorganzational imitation: the effects of outcome salience and uncertainty. Administrative Science Quarterly, 42,472-500.

Henisz, W. J., 2000. The institutional environment for economic growth. Economics and Politics, 12: 1-31.

Henisz, W., Delios, A., 2001. Uncertainty, imitation, and plant location: Japanese multinational corporations, 1990-1996. Administrative Science Quarterly, 46, $443-475$.

Hoffman, A. J., 1999. Institutional evolution and change: environmentalism and the U.S. chemical industry. Academy of Management Journal, 42, 351-371.

Jansson, H., Sandberg, S., 2007. Internationalization of Small and Medium-Sized Enterprises in the Baltic Sea Region. Journal of International Management, this Issue.

Javorcik, B.S. 2004. The composition of foreign direct investment and protection of intellectual property rights: Evidence from transition economies, European Economic Review 48, 39-62.

Johanson, M., 2007. Institutions, exchange, and trust in the transition to a market economy, Journal of International Management, this Issue.

Karhunen, P., 2007. Managing international business operations in a changing institutional context: The Case of St Petersburg hotel industry, Journal of International Management, this Issue. 
Karhunen, P, Löfgren, J., Kosonen, R., 2007. Revisiting the Relationship between ownership and control in International Business operations: Lessons from transition economies. Journal of International Management, this Issue.

King; R. G., Levine, R., 1993. Finance and growth: Schumpeter might be right. The Quarterly Journal of Economics, 108, 717-737.

Kostova, T., 1999. Transnational transfer of strategic organizational practices: A contextual perspective. Academy of Management Review, 24, 308-324.

Kostova, T., Zaheer, S., 1999. Organizational legitimacy under conditions of complexity: The case of the multinational enterprise. Academy of Management Review, 24, 64-81.

LaPorta, R., Lopez-de-Silanes, F., Shleifer, A., Vishny, R.W., 1998. Law and finance. Journal of Political Economy, 106, 1113-1155.

Levine, R., Zervos, S., 1998. Stock markets, banks, and economic growth. American Economic Review, 88, 537-558.

Lu, J.W., 2002. Intra- and inter-organizational imitative behavior: institutional influences on Japanese firms' entry mode choice. Journal of International Business Studies, 33, 19-39.

Lu, J.W., Xu, D., 2006. Growth and Survival of International Joint Ventures: An External-Internal Legitimacy Perspective, Journal of Management 32,1-23. 
March, J.G., 1991. Exploration and exploitation in organizational learning. Organization Science, 2, 71-87.

March, J.G. 2005. Parochialism in the evolution of a research community: The case of organization studies, Management Organization Review 1, 5-22.

Martin, X., Swaminathan, A., Mitchell, W., 1998. Organizational Evolution in the Interorganizational Environment: Incentives and Constraints on International Expansion Strategy. Administrative Science Quarterly, 43, 566-601.

Mayer, T., Muchielli, J.-L., 1998 Strategic Location Behavior: The case of Japanese investments in Europe. Journal of Transnational Management, 3, 131-167.

Megginson, W., Netter, J. 2001. From state to market: A survey of empirical studies on privatization, Journal of Economic Literature 39, 321-389.

Meyer, K. E., Nguyen, H.V., 2005. Foreign Investment Strategies and Sub-national Institutions in Emerging Markets: Evidence from Vietnam. Journal of Management Studies, 42, 63-93.

Meyer, K.E., Tran, Y.T.T., 2006. Market Penetration and Acquisition Strategies for Emerging Economies. Long Range Planning, 39, 177-197.

Meyer K.E., Gelbuda, M., 2006. Process Perspectives in International Business Research, Management International Review, 46, 143-164.

Meyer, J.W., Scott, W.R., 1983. Organizational environments. Beverly Hills, CA: Sage. 
Meyer, J.W., Rowan, B., 1977. Institutionalized organizations: Formal structure as myth and ceremony. American Journal of Sociology, 83, 340-363.

Meyer, K. E., Estrin, S., 2001 'Brownfield entry in emerging markets', Journal of International Business Studies, 32, 575-584.

Meyer, K.E., Peng, M.W., 2005. 'Probing Theoretically into Central and Eastern Europe: Transactions, resources, and institutions', Journal of International Business Studies 36, 600-621.

Meyer, K.E., 2001a. Institutions, Transaction Costs, and Entry Mode Choice in Eastern Europe, Journal of International Business Studies, 32, 357-367.

Meyer, K.E., 2001b. International Business Research on Transition Economies, in: Brewer, T. and Rugman, A. eds: Oxford Handbook of International Business, Oxford: Oxford University Press, p. 716-759.

North, D., 1990. Institutions, Institutional Change, and Economic Performance. Cambridge University Press, Cambridge.

Oliver, C., 1988. The collective strategy framework: An application to competing predictions of isomorphism. Administrative Science Quarterly, 33, 543-561.

Oliver, C., 1991. Strategic responses to institutional processes. Academy of Management Review, 16,145-179.

Oliver, C., 1997. Sustainable competitive advantage: Combining institutional and resource-based views. Strategic Management Journal, 18, 697-713. 
Peng, M. W., Heath, P.S. 1996 The growth of the firm in planned economies in transition: institutions, organizations, and strategic choice. Academy of Management Review, 21, 492-528.

Peng, M.W., Lee, S. H., Wang, D.Y.L. 2005. What determines the scope of the firm over time? A focus on institutional relatedness. Academy of Management Review, 30, 622-633.

Peng, M.W., 2001. How entrepreneurs create wealth in transition economies. Academy of Management Executive, 15, 95-110.

Peng, M.W., 2003 Institutional transitions and strategic choices. Academy of Management Review, 28, 275-296.

Rosenzweig, P.M., Nohria, N., 1994. Influences on human resource management practices in multinational corporations. Journal of International Business Studies, 25, 229-251.

Rosenzweig, P., Singh, J., 1991. Organizational environments and the multinational enterprise. Academy of Management Review, 16, 340-361.

Scott, W.R. 1995. Institutions and Organizations. Thousand Oaks, CA: Sage.

Scott, W.R. 1987. The adolescence of institutional theory. Administrative Science Quarterly, 32, 493-511.

Singh, J.V., Tucker, D.J., House, R.J. 1986. Organizational legitimacy and the liability of newness. Administrative Science Quarterly, 31, 171-193. 
Suchman, M.C., 1995. Managing legitimacy: Strategic and institutional approaches. Academy of Management Review, 20, 571-610.

Svejnar, J., 2002 'Transition economies: Performance and challenges', Journal of Economic Perspectives 16, 3-28.

Tolbert, P., Zucker, L., 1983. Institutional sources of change in the formal structure of organisations: the diffusion of civil service reform, 1880-1935. Administrative Science Quarterly, 28, 22-39.

Westney, D.E. 1993. Institutionalization theory and the multinational corporation. In S. Ghoshal \& D.E. Westney Eds., Organization theory and the multinational corporation: 53-76. New York: St. Martin’s Press.

White, S., 2002. Rigor and relevance in Asian management research: Where are we and where can we go? Asia Pacific Journal of Management, 19, 287-352.

World Bank 1996. World development report: From plan to market: Washington, DC: Oxford University Press.

Wright, M., Filatotchev, I., Hoskisson, R.E., Peng, M.W. 2005. Strategic management research in emerging economies: Challenging the conventional wisdom, Journal of Management Studies 42, 1-33.

Xu, D., Shenkar, O., 2002. Institutional distance and the multinational enterprise. Academy of Management Review, 27, 608-618. 
Yan, A., Gray, B., 2001. Negotiating control and achieving performance in international joint ventures: A conceptual model. Journal of International Management, 7, 295315.

Yiu, D., Makino, S., 2002. The choice between joint venture and wholly-owned subsidiary: An institutional theory perspective, Organization Science 13, 667-683.

Zaheer, S., 1995. Overcoming the liability of foreignness. Academy of Management Journal, 38, 341-363.

Zucker, L. G., 1987. Institutional theories of organization. Annual Review of Sociology, $13,443-464$. 


\section{Appendix 1: \\ Reviewers for the Special Issue}

Otto Anderson (Agder University College, Norway)

Preet Aulakh (York University, Canada)

Bat Batjargal (Peking University, China)

Trevor Buck (Loughborough University, England)

Mark Casson (University of Reading, England)

Sylvie Chetty (Massey University, New Zealand)

Chris Changwa Chung (Florida International University, USA)

Rian Drogendijk (Tilburg University, The Netherlands)

Carl Fey (IIB, Sweden and Stockholm School of Economics in Saint Petersburg, Russia)

Igor Filatotchev (King's College London, England)

Michael Frese (University of Giessen, Germany)

Esra Gencturk (Koc University, Turkey)

Mohsin Habib (University of Massachusetts, Boston)

Paula Jarzabkowski (Aston University, England)

Camilla Jensen (Copenhagen Business School, Denmark)

Jorma Larimo (University of Vaasa, Finland)

Jonathan Levie (Strathclyde University, Scotland)

Dan McAllister (National University of Singapore, Singapore)

Sara McGaughey (University of Leeds, England)

Livia Markoczy (University of Texas Dallas, USA)

Briance Mascarenhas (Rutgers University, USA)

Snejina Michailova (University Auckland, New Zealand)

Rajneesh Narula (University of Reading, England)

Pietro Navvara (University of Messina, Italy)

Jone L. Pearce (University of California Irvine, USA)

Bent Pedersen (Copenhagen Business School, Denmark)

Mike W. Peng (University of Texas Dallas, USA)

Sheila Puffer (Northeastern University, USA)

Slavo Radosevic (Sussex University, England)

Ilkka Ronkainen (Georgetown University, USA)

David Seidl (University of Munich, Germany)

Stoyan Sgourev (ESSEC, France)

Deo Sharma (Stockholm School of Economics, Sweden)

David Smallbone (Middlesex University, England)

Hildy Teegen (George Washington University, USA)

Klaus Uhlenbruck (University of Montana, USA)

Aimin Yan (Boston University, USA)

Tatiana Zalan (University of Melbourne, Australia)

Weiting Zheng (National University of Singapore, Singapore) 
TABLE 1:

Papers in the Special Issue

\begin{tabular}{lllll}
\hline Author(s) & Theory & $\begin{array}{l}\text { Key Concepts and } \\
\text { Relationships }\end{array}$ & Context & Research Methodology \\
\hline Cuervo-Cazurra & $\begin{array}{l}\text { Institutional } \\
\text { economics }\end{array}$ & $\begin{array}{l}\text { Influence of corruption on } \\
\text { level of foreign direct } \\
\text { investment inflows }\end{array}$ & Cross-national & Deductive, quantitative \\
Karhunen & $\begin{array}{l}\text { Institutional theory } \\
\text { (broadly } \\
\text { conceptualized) }\end{array}$ & $\begin{array}{l}\text { The use of business } \\
\text { strategies to deal with macro } \\
\text { and industry level } \\
\text { institutional contexts }\end{array}$ & $\begin{array}{l}\text { Longitudinal, single } \\
\text { location (hotel industry } \\
\text { in St Petersburg) }\end{array}$ & Inductive, qualitative \\
Johansson & $\begin{array}{l}\text { Institutional } \\
\text { economics }\end{array}$ & $\begin{array}{l}\text { The role of trust in exchange } \\
\text { characteristics between } \\
\text { domestic business units }\end{array}$ & $\begin{array}{l}\text { Longitudinal (single } \\
\text { location) }\end{array}$ & Inductive, qualitative \\
$\begin{array}{llll}\text { Jansson and } \\
\text { Sandberg }\end{array}$ & $\begin{array}{l}\text { Internationalization } \\
\text { process model }\end{array}$ & $\begin{array}{l}\text { Entry modes and entry nodes } \\
\text { of foreign investors }\end{array}$ & $\begin{array}{l}\text { Single context (South } \\
\text { Sweden to Baltic Sea }\end{array}$ & $\begin{array}{l}\text { Inductive, quantitative } \\
\text { and qualitative }\end{array}$ \\
$\begin{array}{l}\text { Karhunen, Löfgren } \\
\text { and Kosonen }\end{array}$ & $\begin{array}{l}\text { Institutional } \\
\text { economics }\end{array}$ & $\begin{array}{l}\text { Ownership and control of } \\
\text { foreign operations }\end{array}$ & $\begin{array}{l}\text { Single (Russia) } \\
\text { Inductive, qualitative }\end{array}$ \\
\hline
\end{tabular}

